\title{
Introduction: Targum Studies in London, IOTS 2018
}

\author{
Willem F. Smelik \\ Co-Editor-in-Chief, Aramaic Studies; Professor of Hebrew and Aramaic \\ Literature, Department of Hebrew and Jewish Studies, University College \\ London, London, UK; Marko Feingold Fellow, Paris Lodron Universität \\ Salzburg, Salzburg, Austria \\ uclhwis@ucl.ac.uk
}

This special issue presents a selection of papers held at the 9 th meeting of the International Organization for Targum Studies (IOTS) from 9 to 12 July 2018, at University College London, in conjunction with the Institute of Jewish Studies. Since its inauguration, the IOTs has usually met every three years in conjunction with the International Organization for Old Testament Studies (IOSOT), but after consultation, the executive committee decided to depart from this schedule after the IOTS/IOSOT meeting of 2016. It was agreed to organise independent meetings more often, although a link with larger societies may still be sought if and when it would appear opportune.

The meetings of the IOTs always include an open call for papers to bring together all scholars working in the field of Targum and cognate studies, but also invites papers on specific themes. Two focal points were identified on this occasion: the Aramaic dialects within their Late Antique environment; and the development of the Targums within their wider interpretative milieu. Twentynine papers were presented at the conference over the course of four days, including keynote speeches and a private presentation of selected Aramaic manuscripts by Ilana Tahan, Head of the Hebrew Section at the British Library in London. The initial selection of papers brought together in this volume is not exhaustive.

How Palestinian is Jewish Palestinian Aramaic? In his keynote lecture, ${ }^{1}$ Steve Fassberg surveyed three stages of Jewish Palestinian Aramaic from the origin of its language to the period in which Aramaic became a literary and learned dialect, drawing upon many previous Aramaic dialects. Highlighting some dis-

1 Steven E. Fassberg, 'Jewish Palestinian Aramaic: Chronology, Geography, and Typology', Aramaic Studies 19.1 (2021), this issue. 
tinctive features of Targumic and Talmudic Aramaic, the later Aramaic of Targum Pseudo-Jonathan and the Targums to the Writings are discussed in some detail. Although it has been argued that at least some of these Aramaic writings may not be entirely divested from a vernacular basis, he argues that they cannot have been composed by native speakers, since they do not show the natural development in vocabulary which Syriac displays, both in Arabic loanwords and new Aramaic lexemes. A comparison with Samaritan and Christian Palestinian Aramaic confirms the picture, but also shows that the phenomenon in Jewish Palestinian Aramaic appears to be of a random, scribal nature.

The following studies focus on different aspects of the Targums within their wider interpretative milieu. At the historical, literary and exegetical level, the milieu of composition and transmission relates to the meaning of parallels between targumic and non-targumic exegesis. Exactly how does targumic exegesis relate to its parallels in the Dead Sea Scrolls and rabbinic literature? What are the differences in terms of contents, context and milieu, presentation, and narrative arc? The mere observation of an extant parallel in previous literature does not analyse the relationship in a meaningful way.

Focusing on the earliest period, ${ }^{2}$ Pieter B. Hartog places Targum Jonathan to the Prophets in its intellectual milieu by a careful comparison between the Qumran pesharim and Targum Jonathan, which share an intellectual, priestly tradition and interests. His study is not about literary dependence or dates, but about socio-cultural affinity between various academic endeavours, assuming a strong priestly background to both the world of the pesharim and that of Onqelos and Jonathan.

Gary A. Rendsburg surveys the importance of no less than 650 Cairo Geniza fragments for the textual tradition of the Books of Samuel. ${ }^{3}$ Having read every single one of these, he compares the textual variants found in the Hebrew text to those readings in Targum Jonathan to Samuel, and occasionally the Peshitta, that agree with these variants. He reflects on the question of the nature of agreement between these textual witnesses, whether it reflects polygenesis, hence independent development of a variant reading, or a relation between the witnesses that attests to a stable mode of transmission.

Little attention has been paid to the interconnections between the Targum and the Masoretic cantillation in the past. Miriam Kahana studies the exegetically relevant syntactic agreements between the Masoretic accents and Targum

2 Pieter B. Hartog, 'The Qumran Pesharim and Targum Jonathan to the Prophets', Aramaic Studies 19.1 (2021), this issue.

3 Gary A. Rendsburg, 'Targumic Parallels to Variant Readings of the Book of Samuel amongst the Cairo Geniza Manuscripts', Aramaic Studies 19.1 (2021), this issue. 
Jonathan to the Prophets. ${ }^{4}$ She identifies Masoretic divisions that diverge from the regular pattern, and compares these to both the Targum and the Babylonian reading tradition. Her findings show a remarkable concurrence across divergent reading traditions, including the Targum.

A.J. Berkovitz examines the interaction of Targum of Psalms with rabbinic literature, but goes far beyond its interpretative context by analysing the ways the targumist adopted and adapted certain traditions. ${ }^{5}$ His study is based on the entire Psalter and its Aramaic translation and explores a variety of ways in which the two intersect, or not, which enables a far more precise understanding of how creatively the translator went about translating and the reasons for the choices he made while interacting with an inherited, pre-extant body of tradition.

One of the highlights of the meeting was the surprising convergence of two highly innovative papers on Targum Pseudo-Jonathan by Leeor Gottlieb and Gavin McDowell. ${ }^{6}$ The two strands of the conference came together here: how Palestinian is Targum Pseudo-Jonathan and what is its intellectual milieu? Both authors arrived at the surprising conclusion that the Targum is in fact neither Palestinian nor all that old, but a 12th century Italian composition. The proposed author is R. Menachem ben Shelomo, who also penned Sekhel Tov. Old as the debate about the antiquity, dialect and provenance of TgPsJ is, further sparked by studies into the dialect of the late Targums (to the Writings) and the parallels which Pseudo-Jonathan displayed with the relatively late Midrash Pirqe de Rabbi Eliezer, Gottlieb and McDowell point convincingly into an entirely new direction for the study of the 'Late Targums'. Their contributions will stimulate further discussion and also raise once again important questions about the dialect of TgPsJ.

The conference was made possible through generous grants by an anonymous donor, the European Association for Jewish Studies (EAJs) Conference Grant Programme, and the Institute of Jewish Studies at University College London. We would like to thank these sponsors as well as all the participants in the conference for their contributions to the field.

4 Miriam Kahana, 'Targum Jonathan to the Prophets and the Masoretic Cantillations', Aramaic Studies 19.1 (2021), this issue.

5 Abraham Jacob Berkowitz, 'Parallelism and Beyond: The Relationship between Targum Psalms and Rabbinic Literature', Aramaic Studies 19.1 (2021), this issue.

6 Gavin McDowell, 'The Date and Provenance of Targum Pseudo-Jonathan: The Evidence of Pirqe deRabbi Eliezer and the Chronicles of Moses', Aramaic Studies 19.1 (2021), this issue; Leeor Gottlieb, 'Towards a More Precise Understanding of Pseudo-Jonathan's Origins', Aramaic Studies 19.1 (2021), this issue. 